\title{
Ambient levels of UV radiation Mario Blumthaler*
}

\author{
Address: Department of Medical Physics, Innsbruck Medical University, Austria \\ Email: Mario Blumthaler* - Blumthaler@uibk.ac.at \\ * Corresponding author
}

from Cell Biology of Nitric Oxide and Cell Death in Plants

Yalta, Ukraine, 8-II September 2004

Published: 3I May 2005

BMC Plant Biology 2005, 5(SuppI I):S5 doi:I0.I I86/I47I-2229-5-SI-S5

The levels of solar ultraviolet (UV) radiation at the Earth's surface vary widely, depending on the atmospheric and environmental conditions of the observation site. Under clear sky conditions, the most important parameters are solar zenith angle, total ozone content, amount and type of aerosols, altitude above sea level and albedo of the ground [1]. In addition, attenuation and in special cases amplification by clouds has to be considered. Based on detailed measurements under a large number of different conditions, the effects of the individual parameters on global UV irradiance are quantified. Most of these effects depend strongly on wavelength and many of the effects are most pronounced in the erythemally weighted UVrange.

The effects of the most important parameters are: $1 \%$ decrease in ozone results in an increase of erythemally weighted UV irradiance of about $1.1 \%$ [2]; aerosols can attenuate erythemally weighted UV irradiance by up to $30 \%$, but this depends strongly on amount and type of aerosols [3]; the increase of erythemally weighted UV irradiance with an increase in altitude of $1000 \mathrm{~m}$ amounts between $15 \%$ and $25 \%$, for UVA-radiation this increase is about half that much [4]; an increase of ground albedo by 0.5 will increase erythemally weighted irradiance by about $17 \%$, UVA irradiance by about $10 \%$ [5]; a complete cloud cover attenuates UV irradiance about $40 \%$ less than total irradiance [6].

Long-term changes of solar UV radiation are a complex combination of various effects, where stratospheric ozone depletion, increase of tropospheric ozone levels and effects of global climate change work together. Therefore predictions for future levels of UV radiation are limited to the assumptions of specific scenarios. Future measure- ments will be necessary to monitor any changes on a local and on a global scale.

\section{References}

I. Blumthaler M, Webb A: UVR climatology. In UV effects in Aquatic Organisms and Ecosystems. Comprehensive Series in Photochemistry and Photobiology Volume I. Edited by: Helbling EW, Zagarese H. The Royal Society of Photochemistry, Cambridge; 2003:21-58.

2. Blumthaler M, Salzgeber M, Ambach W: Ozone and ultraviolet-B irradiances: experimental determination of the radiation amplification factor. Photochem Photobiol 1995, 61:159-162.

3. Kylling A, Bais AF, Blumthaler M, Schreder J, Zerefos CS: The effect of aerosols on solar UV irradiances during the PAUR campaign. J Geophys Res 1998, 103:2605I-26060.

4. Blumthaler M, Webb AR, Seckmeyer G, Bais AF, Huber M, Mayer B: Simultaneous Spectroradiometry: A Study of Solar UV Irradiance at Two Altitudes. Geophys Res Let 1994, 2 I:2805-2808.

5. Gröbner J, Albold A, Blumthaler M, Cabot T, De la Casinieri A, Lenoble J, Martin T, Masserot D, Müller M, Philipona R, et al.: Variability of spectral solar ultraviolet irradiance in an Alpine environment. J Geophys Res 2000, 105:2699|-27003.

6. Blumthaler M, Ambach W, Salzgeber M: Effects of cloudiness on global and diffuse UV irradiance in a high-mountain area. Theor Appl Climatol 1994, 50:23-30. 